\title{
Reaction of tert-Alkoxyl and Alkyl Radicals with Styrene Studied by the Nitroxide Radical-Trapping Technique
}

\author{
Tomoyuki Nakamura, ${ }^{\dagger, \ddagger}$ W. Ken Busfield, ${ }^{\dagger}$ Ian D. J enkins, ${ }^{*, \dagger}$ Ezio Rizzardo, ${ }^{\S}$ \\ San H. Thang, ${ }^{\S}$ and Shuji Suyama ${ }^{\ddagger}$ \\ Faculty of Science and Technology, Griffith University, Nathan QLD 4111, Australia, CSIRO, \\ Division of Chemicals and Polymers, Private Bag 10, Clayton South, MDC, Victoria 3169, Australia, and \\ Fine Chemicals and Polymers Research Laboratory, NOF Corporation, Taketoyo-cho,
}

Chita-gun, Aichi 470-23, J apan

Received April 28, $1997^{\otimes}$

\begin{abstract}
The reactions of tert-alkyl peroxypivalates $\mathbf{l}(\mathrm{R}=$ methyl, ethyl, and $\mathrm{n}$-propyl) with styrene in the presence of the free-radical scavenger (1,1,3,3-tetramethyl-2,3-dihydro-1H-isoindol-2-yl)oxyl (2) have been studied at $60{ }^{\circ} \mathrm{C}$. tert-Butyl and tert-alkoxyl radicals (tert-butoxyl, tert-pentyloxyl, and terthexyloxyl radicals) were generated from the thermolysis of $\mathbf{1}$, and the derivative alkyl radicals (methyl, ethyl, n-propyl, and 4-hydroxy-4-methylpentyl radicals) were formed by subsequent unimolecular reactions ( $\beta$-scission and 1,5-H shift) of the corresponding tert-alkoxyl radicals. The extent of the unimolecular reactions of the tert-alkoxyl radicals (versus addition to styrene) and the relative reactivity of alkyl radicals toward addition to styrene were obtained from the competitive addition/trapping reactions. The absolute rate constants for the addition of tert-butyl, ethyl, methyl, and n-propyl radicals to styrene at $60^{\circ} \mathrm{C}$ were estimated to be $\left(7.4,4.7,5\right.$, and 5.4) $\times 10^{5} \mathrm{M}^{-1} \mathrm{~s}^{-1}$, respectively.
\end{abstract}

\section{Introduction}

The factors controlling the interaction of free radicals with ol efins are of great importance in polymer chemistry as well as in organic synthesis and have been summarized in several reviews ${ }^{1}$ and books. ${ }^{2-4}$ In general, the rate and orientation of free-radical addition to ol efins have been shown to depend on the "complex interplay of polar, steric, and bond strength terms". Recently, Fischer et al. have determined the main factors controlling the reactivity of alkyl radicals toward addition to a large series of alkenes. They have reported, for instance, that, for tert-butyl $\left.\right|^{5}$ and 2-hydroxy-2-propyl radicals, ${ }^{6}$ addition rates are largely governed by polar effects, whereas, for methyl radical $\mathrm{s}^{7}$ the addition rates are controlled by both polar effects and the overall reaction enthalpy.

As part of an ongoing study into the interaction process in free-radical polymerization, we have used tert-alkyl peroxypivalates $\mathbf{1}$ as a source of both tert-alkoxyl and al kyl radicals and the aminoxyl 2 ((1,1,3,3-tetramethyl2,3-dihydro-1H-isoindol-2-yl)oxyl) as a radical scavenger.

Peroxypivalates $\mathbf{1}$ are commercial initiators used in the radical polymerization of vinyl monomers such as styrene

* To whom correspondence should be addressed. Tel.: (07) 3875 7476. Fax: (07) 3875 7656. E-mail: I.D.J enkins@sct.gu.edu.au. ${ }^{\dagger}$ Griffith University.

₹ NOF Corporation.

$\S$ CSIRO.

${ }^{\otimes}$ Abstract published in Advance ACS Abstracts, J uly 1, 1997.

(1) (a) Rüchardt, C. Angew. Chem.. Int. Ed. Engl. 1970, 9, 830-

843. (b) Beckwith, A. L. J. Tetrahedron 1981, 37, 3073-3100. (c)

Tedder, J. M.; Walton, J. C. Tetrahedron 1980, 36, 701-707. (d)

Tedder, J. M. Angew. Chem., Int. Ed. Engl. 1982, 21, 401-410. (e)

Giese, B. Angew. Chem., Int. Ed. Engl. 1983, 22, 753-764. (f) Giese,

B. Angew. Chem., Int. Ed. Engl. 1989, 28, 969-980.

(2) Moad, G.; Solomon, D. H. The Chemistry of Free Radical Polymerization; Elsevier Ścience: Oxford, 1995.

(3) Motherwell, W. B.: Crich, D. Free Radical Chain Reactions in Organic Synthesis; Academic Press: New York, 1992.

(4) Fossey, J .; Lefort, D.; Sorba, J. Free Radicals in Organic Chemistry; Masson: Paris, 1995.

(5) Münger, K.; Fischer, H. Int. J . Chem. Kinet. 1985, 17, 809-829.

(6) Héberger, K.; Fischer, H. Int. J . Chem. Kinet. 1993, 25, 913920. 439.
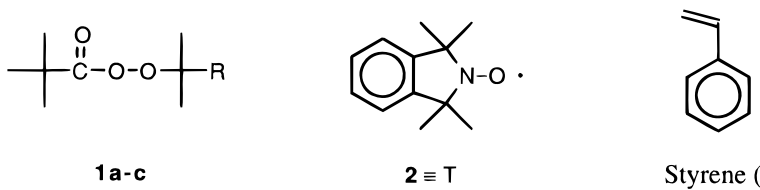

(a) $\mathrm{R}=\mathrm{Me}$

(b) $\mathrm{R}=\mathrm{Et}$

(c) $\mathrm{R}=\mathrm{n}-\mathrm{Pr}$

and (meth)acrylates. ${ }^{8}$ They are known to undergo a concerted two-bond scission to generate the corresponding tert-alkoxyl radicals $\mathbf{3}$ and tert-butyl radicals (Scheme 1). ${ }^{9}$ The tert-alkoxyl radicals $\mathbf{3}$ can also produce alkyl radicals by subsequent unimolecular decomposition. The radical-trapping technique, employing the stable aminoxyl radical $\mathbf{2}$, has been widely used to study the details of the initiation steps in free-radical polymerization. ${ }^{10}$ Using peroxypivalates as initiators, the technique provides not only details of the reactions of alkoxyl radicals but also information on the reactivities of al kyl radicals toward monomers. For example, we have previously shown ${ }^{11,12}$ (i) that, in contrast to tert-butoxyl radicals (3a), tert-pentyloxyl (3b) and tert-hexyloxyl radicals (3c) undergo rapid unimolecular reactions ( $\beta$-scission and 1,5hydrogen shift), resulting in a remarkable reduction of

(8) (a) Sheppard, C. S. In Encyclopedia of Polymer Science and Engineering, 2nd ed.; Klingsberg, A., Piccininni, R. M., Salvatore, A., Baldwin, T., Eds.; Wiley-Interscience: New York, 1988; Vol. 11, pp 1-21. (b) Suyama, S.; Nakamura, T.; I shigaki, H. J pn. Kokai Tokkyo Koho 841417; Chem. Abstr. 1996, 124, 346158.

(9) (a) Bartlett, P. D.; Simons, D. M. J . Am. Chem. Soc. 1960, 82 1753-1756. (b) Koenig, T.; Wolf, R. J . Am. Chem. Soc. 1967, 89, 29482952. (c) Lorand, J . P.; Chodroff, S. D.; Wallace, R. W. J . Am. Chem. Soc. 1968, 90, 5266-5267. (d) Pryor, W. A.; Morkved, E. H.; Bickley, H. T. J . Org. Chem. 1972, 37, 1999-2005.

(10) (a) Rizzardo, E.; Solomon, D. H. Polym. Bull. 1979, 1, 529534. (b) Moad, G.; Solomon, D. H. In ComprehensivePolymer Science: Eastmond, G. C., Ed.; Pergamon: London, 1989; Vol. 3, pp 116-117. (c) Bottle, S. E.; Busfield, W. K.; Heiland, K.; J enkins, I. D.; Meutermans, W.; Monteiro, M. In Progress in Pacific Polymer Science 3; Ghiggino, K. P., Ed.; Springer-Verlag: Berlin, Heidelberg, 1994; p 85. (d) Busfield, W. K.; Grice, I. D.; J enkins, I. D. Aust. J . Chem. 1995 48, 625-634 and references cited therein.

(11) Nakamura, T.; Busfield, W. K.; J enkins, I. D.; Rizzardo, E.; Thang, S. H.; Suyama, S. J . Am. Chem. Soc. 1996, 118, 10824-10828. 
Table 1. Yields of All Products Relative to the Overall Yield of tert-Butyl Radical-Derived Products (4 and 5) in the Reaction of tert-Alkyl Peroxypivalates 1 with Styrene in the Presence of Nitroxide 2 at $60^{\circ} \mathrm{C}^{\mathrm{a}}$

\begin{tabular}{|c|c|c|c|c|c|c|c|c|c|c|}
\hline \multirow[b]{3}{*}{ run } & \multirow[b]{3}{*}{ initiator } & \multicolumn{9}{|c|}{ relative product yields (\%) } \\
\hline & & \multicolumn{2}{|c|}{ tert-butyl radical-derived products } & \multicolumn{7}{|c|}{ tert-alkoxyl radical-derived products } \\
\hline & & $\begin{array}{c}\mathbf{4} \\
B u^{t}-T\end{array}$ & $\begin{array}{c}\mathbf{5} \\
\mathrm{Bu}^{\mathrm{t}}-\mathrm{S}-\mathrm{T}\end{array}$ & $\begin{array}{c}\mathbf{6} \\
\mathrm{I}-\mathrm{S}-\mathrm{T}\end{array}$ & $\begin{array}{c}7 \\
M e^{-}-T\end{array}$ & $\begin{array}{c}\mathbf{8} \\
M e-S-T\end{array}$ & $\begin{array}{c}9 \\
\mathrm{R}-\mathrm{T}\end{array}$ & $\begin{array}{c}10 \\
R-S-T\end{array}$ & $\underset{R^{\prime}-T}{11}$ & $\begin{array}{c}12 \\
R^{\prime}-S-T\end{array}$ \\
\hline 1 & & 84.9 & 15.1 & 98.6 & 1.3 & 0.1 & & & & \\
\hline 2 & DTBPO & & & 98.6 & 1.2 & 0.2 & & & & \\
\hline 3 & $\mathbf{1 b}$ & 84.7 & 15.3 & 46.7 & 0.7 & 0.1 & 48.7 & 3.8 & & \\
\hline 4 & 1c & 84.4 & 15.6 & 32.3 & 0.5 & 0.1 & 32.1 & 3.1 & 29.5 & 2.6 \\
\hline
\end{tabular}

${ }^{a}[\mathbf{1}]_{0}=[\mathbf{2}]_{0}=0.040 \mathrm{M}$, reaction time: $1.0 \mathrm{~h} .{ }^{\mathrm{b}}$ DTBPO: di-tert-butyl peroxyoxalate, $[\mathrm{DTBPO}]_{0}=0.040 \mathrm{M},[\mathbf{2}]_{0}=0.090 \mathrm{M}$, reaction time: $1.5 \mathrm{~h}$.

\section{Scheme 1}

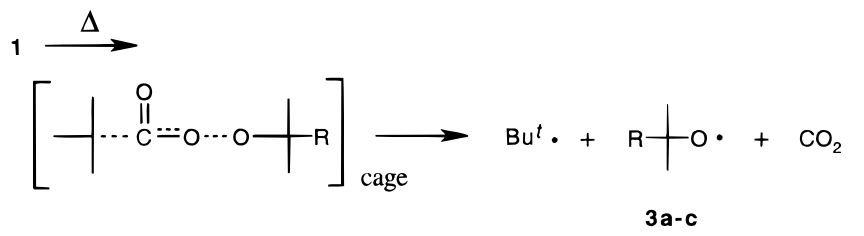

(a) $\mathrm{R}=\mathrm{Me}$

(b) $\mathrm{R}=\mathrm{Et}$

(c) $\mathrm{R}=\mathrm{n}-\mathrm{Pr}$

the extent of hydrogen abstraction from methyl methacrylate (MMA), and (ii) that alkyl radicals formed in the reaction, that is, methyl, ethyl, n-propyl, and 4-hydroxy4-methylpentyl radicals, undergo selective tail addition to MMA with absolute rate constants of $(1.0,0.86,1.0$, 1.1 , and 2.2) $\times 10^{6} \mathrm{M}^{-1} \mathrm{~s}^{-1}$, respectively.

In the present work, we report a study of the reactions of tert-alkoxyl and alkyl radicals with styrene. There have only been two previous reports of the reaction of tert-alkoxyl radicals with styrene, one tert-butoxyl ${ }^{13}$ and the other $\alpha$-cumyloxyl radicals. ${ }^{14}$ In both cases, the major reaction was alkoxyl radical addition.

\section{Results and Discussion}

In a typical reaction, a styrene solution of tert-alkyl peroxypivalate $\mathbf{1 a}-\mathbf{c}(0.040 \mathrm{M})$ and the aminoxyl $\mathbf{2}(0.040$ $\mathrm{M})$ was degassed and then heated at $60^{\circ} \mathrm{C}$ for $1 \mathrm{~h}$. Most of the excess monomer was removed at reduced pressure, and the residue was then analyzed by HPLC, HPLCMS, and NMR. Alkoxyamines 4-12 (Chart 1) were formed, and the percentage yields relative to the overall yield of tert-butyl radical-derived products (4 and 5) are shown in Table 1. A mechanism for the formation of these products is presented in Scheme 2. Most (ca. 85\%) of the tert-butyl radicals generated from the acyl moiety of $\mathbf{1}$ were directly trapped by the aminoxyl radicals to form compound 4 (eq 1). The remainder (ca. 15\%) underwent tail addition to styrene followed by trapping to give compound 5 (eq 2). On the other hand, tertalkoxyl radicals underwent a variety of reactions to form compounds 6-12 (eqs 3-9). It is apparent from Table 1 that the total yield of tert-alkoxyl radical-derived products is identical to that of tert-butyl radical-derived products in all runs. This is consistent with the fact that peroxypivalates 1 cleanly generate equimolar amounts of the two radicals ${ }^{9,11,12}$ (Scheme 1 ).

(12) (a) Nakamura, T.; Busfield, W. K.; J enkins, I. D.; Rizzardo, E. Thang, S. H.; Suyama, S. Macromolecules 1996, 29, 8975-8976. (b) Nakamura, T.; Busfield, W. K.; J enkins, I. D.; Rizzardo, E.; Thang, S. H.; Suyama, S. Macromolecules 1997, 30, 2843-2847.

(13) Moad, G.; Rizzardo, E.; Solomon, D. H. Macromolecules 1982, $15,909-914$.

(14) Rizzardo, E.; Serelis, A. K.; Solomon, D. H. Aust. J . Chem. 1982 35, 2013-2024.

\section{Chart 1}

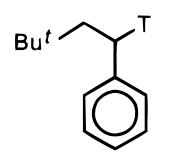

$5 \equiv \mathrm{Bu}^{t}-\mathrm{S}-\mathrm{T}$

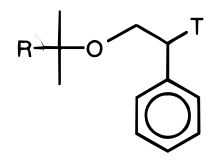

$6 \mathrm{a}-\mathrm{c} \equiv \mathrm{I}-\mathrm{S}-\mathrm{T}$
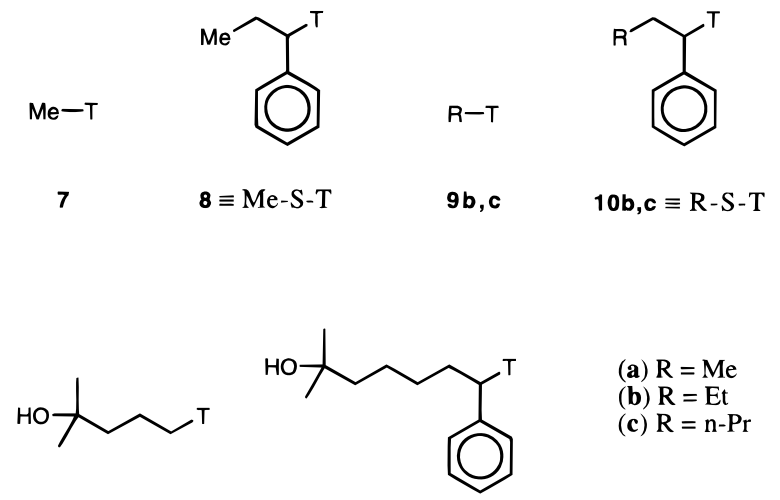

$11 \equiv R^{\prime}-T \quad 12 \equiv R^{\prime}-S-T$
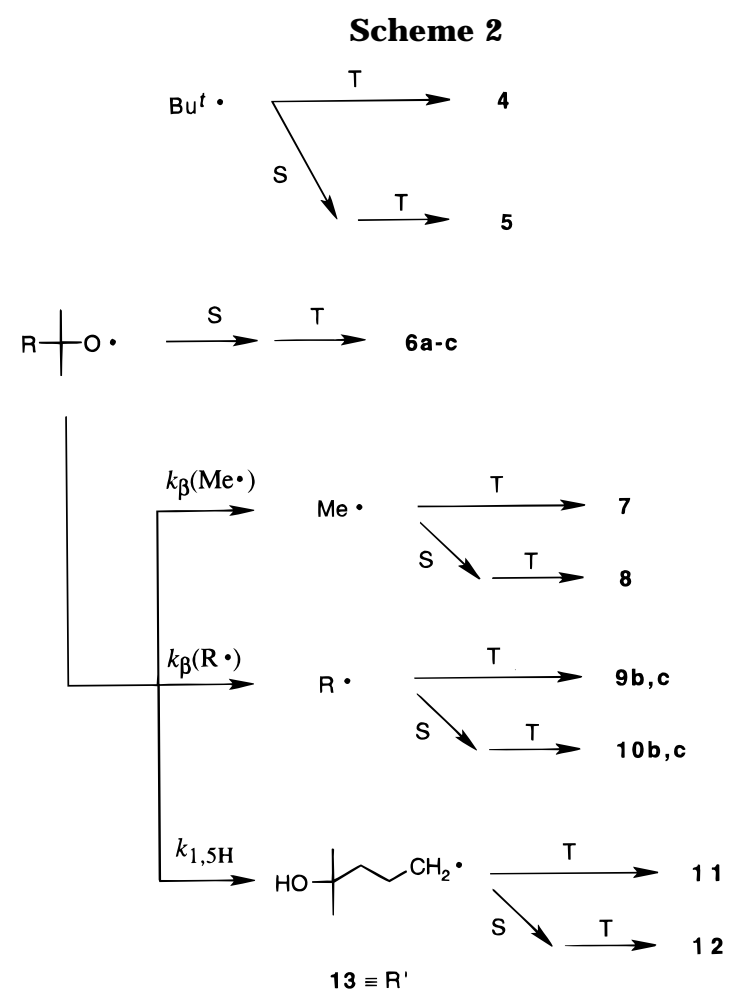

In the reaction of tert-butyl peroxypivalate $\mathbf{1 a}$ with styrene, as expected, alkoxyamines 6a, 7, and 8 were obtained from tert-butoxyl radicals $\mathbf{3 a}$. The ratio of their 
Table 2. Proportion (\%) of Reactions of tert-Alkoxy Radicals with Styrene and $\mathrm{MMA}^{\mathrm{a}}\left(60^{\circ} \mathrm{C}\right)$

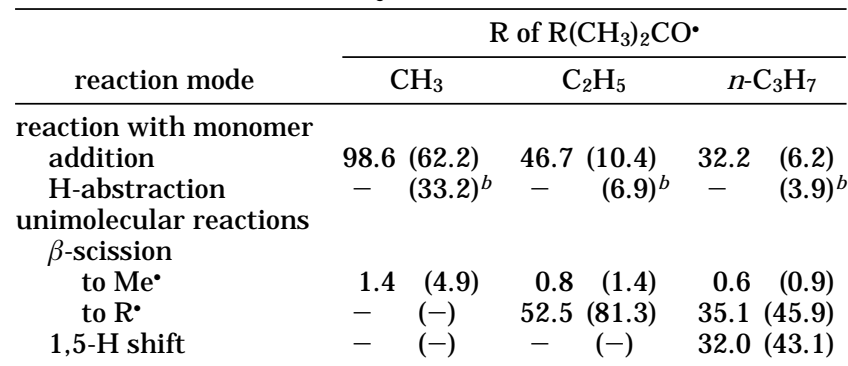

a The values in parentheses were obtained in the reaction with MMA (refs 11 and 12). ${ }^{b}$ Total proportion of $\mathrm{H}$-abstraction from allylic and ester methyl groups of MMA.

relative yields was virtually identical to the literature value ${ }^{13}$ and the result found in a separate experiment that was carried out using di-tert-butyl peroxyoxalate as an exclusive source of $\mathbf{3 a}$ (run 2 in Table 1). Thus, the great majority of $3 \mathbf{a}$ underwent sel ective tail addition to styrene (eq 3), while $\beta$-scission of $\mathbf{3 a}$ to generate methyl radicals occurred to a very small extent $(<2 \%$ ) (eqs 4 and 5).

An anal ogous reaction of tert-pentyl peroxypivalate $\mathbf{1 b}$ with styrene resulted in the formation of alkoxyamines $\mathbf{6 b}, \mathbf{9 b}$, and $\mathbf{1 0 b}$ in addition to the products $(4,5,7$, and 8) found in the tert-butoxyl radical system. Table 1 shows that the major reaction pathways for reaction of tertpentyloxyl radicals $\mathbf{3 b}$ with styrene were both addition (to form $\mathbf{6 b}$ ) and $\beta$-scission to generate ethyl radicals [to form $\mathbf{9 b}$ and $\mathbf{1 0 b}$ (eqs 6 and 7)], which occurred to nearly the same extent (46.7\%:52.5\%, respectively).

On the other hand, in the reaction of tert-hexyl peroxypivalate with styrene, alkoxyamines 6c (addition product), 9c, and 10c (n-propyl radical-derived products), and 11 and 12 (4-hydroxy-4-methylpentyl radical 13 derivatives) were obtained in addition to the alkoxyamines $\mathbf{4 , 5}, \mathbf{7}$, and $\mathbf{8}$. Thus tert-hexyloxyl radicals $3 \mathbf{c}$ undergo intermolecular hydrogen abstraction $(1,5-\mathrm{H}$ shift), producing al kyl radicals $\mathbf{1 3}$ (eqs 8 and 9) in styrene as well as in MMA. ${ }^{12}$ The ratio of the product yields $(\mathbf{6 c}: 9 \mathbf{c}+$ 10c: $11+\mathbf{1 2}=32.2: 35.1: 32.0$ ) shows that the extent of the three major pathways in the reaction of $\mathbf{3 c}$ with styrene, i.e., addition, $\beta$-scission to form n-propyl radicals, and 1,5-H shift, were al most the same.

Reaction of tert-Alkoxyl Radicals with Styrene. The reactions of tert-alkoxyl radicals with styrene studied here, together with the results obtained previously in MMA, 11,12 are summarized in Table 2 . It can be seen from Table 2 that the proportion of unimolecular reactions depends on the alkyl group (R) of tert-alkoxyl radicals, and it increases in the order $\mathrm{R}=\mathrm{Me}(\mathbf{3 a})<\mathrm{Et}$ (3b) $<\mathrm{n}-\operatorname{Pr}(\mathbf{3 c})$. Although this trend is the same as that observed in the reaction with MMA, the total proportion of unimolecular reactions was significantly lower than that observed in the MMA system. With 3c, for example, the proportion was ca. $68 \%$ in styrene but ca. $90 \%$ in MMA. Presumably, this is mainly due to the increased rate of addition of tert-alkoxyl radicals to styrene. Alkoxyl radicals (which are electrophilic) react more rapidly with el ectron-rich monomers such as styrene than with electron-deficient monomers such as MMA. For example, the relative reactivity of the double bonds of styrene and of MMA toward addition of tert-butoxyl radicals has been reported to be $1: 0.189$ in benzene at $60^{\circ} \mathrm{C} .{ }^{15}$

(15) Bednarek, D.; Moad, G.; Rizzardo, E.; Solomon, D. H. Macromolecules 1988, 21, 1522-1528.

\section{Scheme 3}

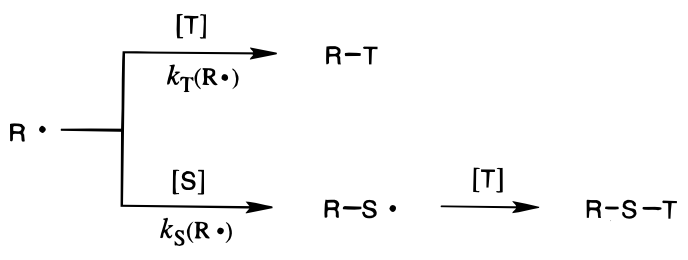

Table 3. Yields of All Products Relative to the Overall Yield of tert-Butyl Radical-Derived Products (4 and 5) in the Reaction of tert-Pentyl Peroxypivalates $1 \mathbf{b}$ with Styrene in the Presence of Nitroxide 2 at $60^{\circ} \mathrm{C}^{\mathrm{a}}$

\begin{tabular}{|c|c|c|c|c|c|c|c|c|}
\hline \multirow[b]{3}{*}{ run } & \multirow[b]{3}{*}[2]{$_{0} / \mathrm{M}$} & \multicolumn{7}{|c|}{ relative product yields (\%) } \\
\hline & & \multicolumn{2}{|c|}{$\begin{array}{l}\text { tert-butyl radical- } \\
\text { derived products }\end{array}$} & \multicolumn{5}{|c|}{$\begin{array}{c}\text { tert-pentyloxyl } \\
\text { radical-derived products }\end{array}$} \\
\hline & & 4 & 5 & $6 \mathbf{b}$ & 7 & 8 & 9b & 10b \\
\hline 5 & 0.035 & 83. & 16.4 & 46. & 0.7 & 0.2 & 48.3 & \\
\hline 6 & 0.040 & 85 & 14 & 46.7 & 0.7 & 0.1 & 48.7 & \\
\hline 7 & 0.050 & 87. & 12 & 46.6 & 0.7 & 0.1 & 49.6 & \\
\hline 8 & 0.060 & 89. & 10. & 46.6 & 0.8 & 0.1 & 50.0 & 2.4 \\
\hline 9 & 0.080 & 9 & 8.2 & 46.7 & 0.8 & 0.1 & 50.6 & 1. \\
\hline
\end{tabular}

The (competitive) $\beta$-scission of alkoxyl radicals $\mathbf{3} \mathbf{b}$ and 3c generated two alkyl radicals, methyl and the corresponding radicals $\left(\mathrm{R}^{\bullet}\right)$ (see Scheme 2 ). The relative scission rates to form these two radicals from tert-alkoxyl radicals can be estimated from the ratios of $(\mathbf{9 b}+\mathbf{1 0 b})$ and $(\mathbf{9 c}+\mathbf{1 0 c})$ to $(\mathbf{7}+\mathbf{8})$ as follows: $\mathrm{k}_{\beta}\left(\mathrm{Me}^{\circ}\right): \mathrm{k}_{\beta}\left(\mathrm{Et} \mathrm{t}^{\circ}\right)=$ 1:131 (for 3b) and $k_{\beta}\left(M^{*}\right): k_{\beta}(n-P r \cdot)=1: 117$ (for 3c). Thus, the rate of alkyl radical fragmentation from tertalkoxyl radicals increased in the order $\mathrm{Me}^{*} \ll \mathrm{n}-\mathrm{Pr}^{*}<\mathrm{Et}^{*}$. Similarly, the relative yields of products derived from n-propyl and 4-hydroxy-4-methylpentyl radicals $(\mathbf{1 1}+\mathbf{1 2}$ : $9 c+10 c)$ shows that the relative rate of $k_{1,5 H}: k_{\beta}(n-P r \cdot)$ $=0.91: 1.0$. The values obtained here are very close to thosefound in the MMA system ${ }^{12}\left[\mathrm{k}_{\beta}\left(\mathrm{Me}^{*}\right): \mathrm{k}_{\beta}\left(\mathrm{Et}^{*}\right)=1: 116\right.$ (for 3b), $\mathrm{k}_{\beta}\left(\mathrm{Me}^{*}\right): \mathrm{k}_{\beta}\left(\mathrm{n}-\mathrm{Pr}{ }^{*}\right)=1: 102$ (for $\left.3 c\right)$ and $\mathrm{k}_{1,5 \mathrm{H}}: \mathrm{k}_{\beta}(\mathrm{n}$ $\left.\left.\operatorname{Pr}{ }^{\circ}\right)=0.94: 1.0\right]$; thus, there is no significant solvent effect on the unimolecular reactions of tert-alkoxyl radicals in styrene versus MMA.

Reaction of Alkyl Radicals with Styrene. Alkyl radicals formed in the reaction underwent competitive addition/trapping as shown in Scheme 3, where $k_{s}$ and $\mathrm{k}_{\mathrm{T}}$ are the general rate constants for the reaction of alkyl radicals $R^{\cdot}$ with styrene and $T$, respectively. A series of experiments was carried out using $\mathbf{l b}$ in order to study the addition reactions of tert-butyl and ethyl radicals with styrene. Thus, a styrene solution of $\mathbf{1 b}(0.040 \mathrm{M})$ with various initial concentrations of $\mathbf{2}$ was reacted at $60^{\circ} \mathrm{C}$ for $0.5 \mathrm{~h}$ (Table 3). The ratio of products derived from competitive reactions of tert-butyl and ethyl radicals should be inversely proportional to [T] as shown in eq 12.

$$
\frac{[R-S-T]}{[R-T]}=\frac{k_{S}\left(R^{\bullet}\right)[S]}{k_{T}\left(R^{*}\right)} \frac{1}{[T]}
$$

Since the conversion of pivalate is very low (half life of $\mathbf{~} \mathbf{b}$ at $60^{\circ} \mathrm{C}$ is ca. $5.5 \mathrm{~h}$ in cumene), ${ }^{16}$ the amounts of $\mathrm{S}$ and $T$ consumed are very small, and these concentrations can be assumed to be constant and equal to the initial values $\left([S]_{0}=8.7 \mathrm{M}\right.$ and $[\mathrm{T}]_{0}$ as shown in Table 3$)$. The plots of $\mathrm{R}-\mathrm{S}-\mathrm{T} / \mathrm{R}-\mathrm{T}$ vs $1 /[\mathrm{T}]_{0}$ for both alkyl radicals

(16) Komai, T.; Matsuyama, K.; Matsushima, M. Bull. Chem. Soc J pn. 1988, 61, 1641-1649. 


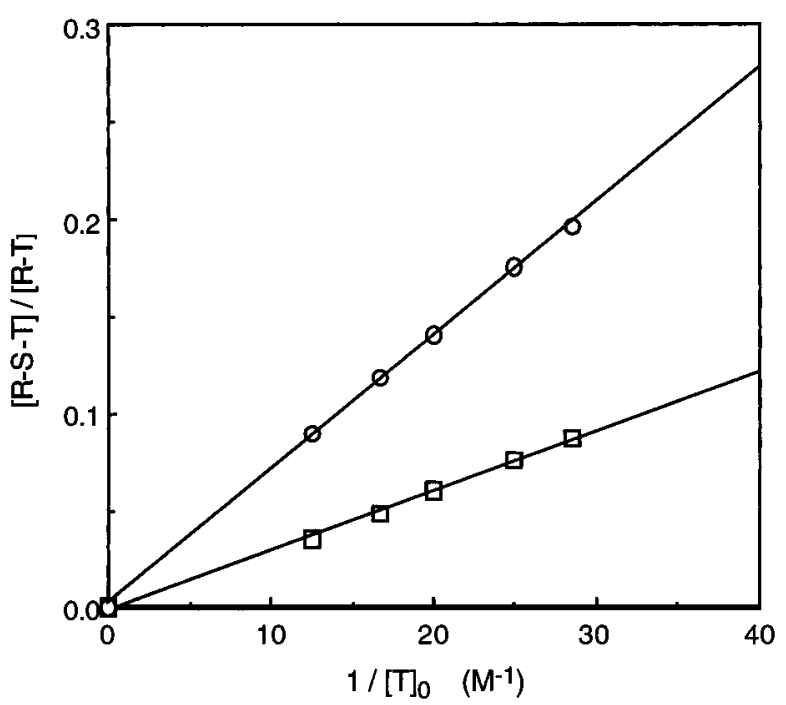

Figure 1. $[R-S-T] /[R-T]$ vs $1 /[T]_{0}$ plots for alkyl radicals: tert-butyl radicals $(\bigcirc)$; ethyl radicals $(\square)$.

Table 4. Absolute Rate Constants for Alkyl Radical Addition to Styrene and MMA $\left(60^{\circ} \mathrm{C}\right)$

\begin{tabular}{clc}
\hline & \multicolumn{2}{c}{ rate constants $\left(\mathrm{M}^{-1} \mathrm{~s}^{-1}\right)$} \\
\cline { 2 - 3 } alkyl radicals & $\mathrm{ks} \times 10^{-5}$ & $\mathrm{kMMA}^{\mathrm{a}} \times 10^{-6}$ \\
\hline $\mathrm{CH}_{3}{ }^{\bullet}$ & $\mathrm{ca} .5(5.6)^{\mathrm{b}}$ & 1.0 \\
$\mathrm{C}_{2} \mathrm{H}_{5}{ }^{\circ}$ & 4.6 & 0.86 \\
$\mathrm{n}^{-} \mathrm{C}_{3} \mathrm{H}_{7}$ & 5.3 & 1.0 \\
$\mathbf{1 3}$ & 4.9 & 1.1 \\
$\mathrm{Bu}^{\mathrm{t}}$ & 7.2 & 2.2
\end{tabular}

a From ref 12 . ${ }^{b}$ Calculated from the data in ref 7 .

(Figure 1) showed the linear relationship ( $r=0.999$ for each plot). From the slope of each plot and the values of $\mathrm{k}_{\mathrm{T}}\left(\mathrm{Bu}^{\mathrm{t}^{\circ}}\right)^{17}=9.1 \times 10^{8} \mathrm{M}^{-1} \mathrm{~s}^{-1}$ and $\mathrm{k}_{\mathrm{T}}$ (primary radicals) ${ }^{18}$ $=1.3 \times 10^{9} \mathrm{M}^{-1} \mathrm{~s}^{-1}$, the absolute rate constants for addition to styrene $\left(\mathrm{k}_{\mathrm{s}}\right)$ for tert-butyl and ethyl radicals were estimated to be $\left(7.2\right.$ and 4.6) $\times 10^{5} \mathrm{M}^{-1} \mathrm{~s}^{-1}$, respectively. Moreover, the corresponding ratios (5/4, $10 \mathrm{c} / 9 \mathrm{c}$, and $\mathbf{1 2} / \mathbf{1 1}$ ) obtained from the reaction of $\mathbf{1 c}$ with styrene (run 4 in Table 1) provided the relative values of ks for tert-butyl, n-propyl, and 4-hydroxy-4-methylpentyl radicals (13) as follows:

$$
\mathrm{k}_{\mathrm{S}}\left(\mathrm{Bu}^{\mathrm{t}}\right): \mathrm{k}_{\mathrm{S}}\left(\mathrm{n}-\mathrm{Pr}^{*}\right): \mathrm{k}_{\mathrm{S}}(\mathbf{1 3})=1.0: 0.74: 0.68
$$

The absol ute rate constants were estimated by taking the value of $\mathrm{k}_{\mathrm{s}}\left(\mathrm{Bu}^{\mathrm{t}^{*}}\right)$, as shown in Table 4. It can be seen from Table 4 that for all alkyl radicals studied here the addition rate toward styrene is lower than toward MMA. This result is qualitatively consistent with other work

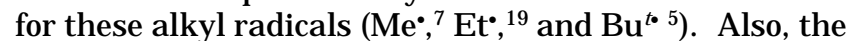
relative reactivities of alkyl radicals increased in the same order, i.e., $\mathrm{Et}^{*}<\mathrm{n}-\mathrm{Pr}^{*}<\mathrm{Bu}^{\mathrm{t}}$, in both monomer systems. This result can be explained in terms of polar factors and can be described using frontier orbital theory. ${ }^{3,4}$ That is, the addition rate for nucleophilic radicals increases with a decrease in the energy difference between the SOMO of the alkyl radical and the LUMO of the monomer (see Figure 2). Therefore, toward the same alkyl radical, since the energy of the LUMO of

(17) Beckwith, A. L. J .; Bowry, V. W.; Moad, G. J . Org. Chem. 1988, $53,1632-1641$.

(18) This value is the rate constant for trapping by $\mathbf{2}$ of $n$-nonyl radicals. In this paper, it was used for all primary radicals. Bowry, V. W.; Ingold, K. U. J . Am. Chem. Soc. 1992, 114, 4992-4996.

(19) J ames, D. G. L.; Ogawa, T. Can. J . Chem. 1965, 43, 640-649.

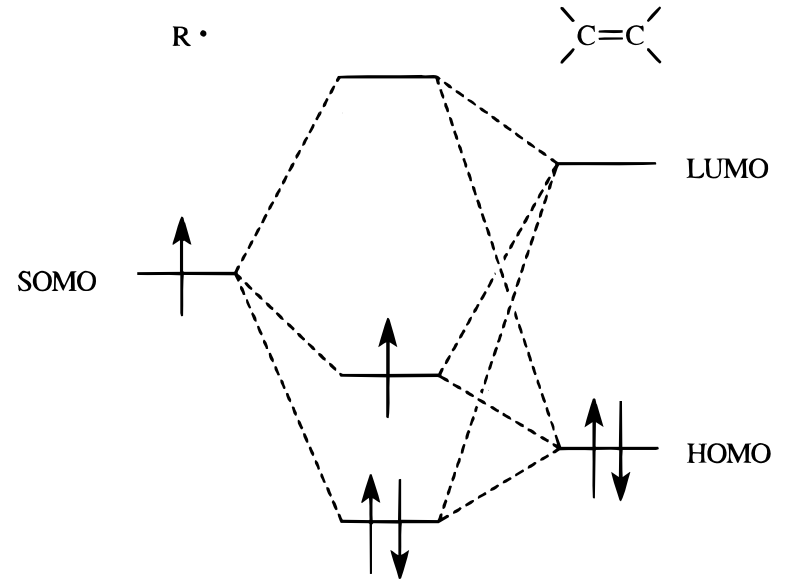

Figure 2. Interaction between the SOMO of a free radical and the HOMO and LUMO of an alkene.

styrene (electron-rich monomer) is higher than that of MMA (electron-deficient monomer), the SOMO-LUMO energy difference for styrene is larger than for MMA; thus, styrene exhibits a lower reactivity toward alkyl radicals than does MMA. On the other hand, toward the same monomer, the incorporation of electron-donating groups to the radical center carbon increases the energy of the SOMO of the alkyl radical [which can be approximated by the decrease in ionization potential (IP/ $\mathrm{eV})$, i.e., Et• $\left.(8.13)^{20}<\mathrm{n}-\mathrm{Pr} \cdot(8.09)^{20}<\mathrm{Bu}^{\mathrm{t} \cdot}(6.70)^{20}\right]$, and so the addition rate increases as observed. However, the relatively high reactivity of methyl radicals toward both monomers cannot be explained by the SOMO-LUMO interaction. Fischer et al..$^{5}$ noted that for radicals with higher IP [methyl (9.84 eV) and trifluoromethyl (10.85 $\mathrm{eV})$ ], the SOMO-HOMO interaction will be more important and polar factors may be less pronounced. Also, the dependence of addition rate on the reaction enthal py as well as polar effects has been reported for methyl radical reactions. ${ }^{7}$

In conclusion, in contrast to tert-butoxyl radicals $\mathbf{3 a}$, a high proportion of unimolecular reactions ( $\beta$-scission and $1,5-\mathrm{H}$ shift) of tert-pentyloxyl $\mathbf{3 b}$ and tert-hexyloxyl radicals $3 c$ was observed in reactions with styrene as well as in reactions with MMA. This means that when $\mathbf{1 b}$ or 1c are used as initiators for the polymerization of styrene (or MMA), the main initiating radicals are alkyl radicals (tert-butyl and ethyl in the case of $\mathbf{1 b}$, and tert-butyl, propyl, and 4-hydroxy-4-methyl pentyl radicals in the case of 1c). The rate constants for alkyl radical addition to styrene were estimated to be $\mathrm{Et}^{-}\left(4.7 \times 10^{5}\right), \mathbf{1 3}(5.0 \times$ $\left.10^{5}\right)$, n-Pr• $\left(5.4 \times 10^{5}\right)$, and $\mathrm{Bu}^{\text {tै }}\left(7.4 \times 10^{5} \mathrm{M}^{-1} \mathrm{~s}^{-1}\right)$; i.e., the rate constant increases with increasing nucleophilicity of the alkyl radical.

\section{Experimental Section}

Materials. Styrene was purified by distillation and stored in a refrigerator $\left(-20^{\circ} \mathrm{C}\right)$. tert-Alkyl peroxypivalates $\mathbf{1 a}-\mathbf{C}$ were prepared by the reaction of pivaloyl chloride with the corresponding alkyl hydroperoxide as described in the previous papers. ${ }^{12,16}$ The half-life of these peroxypivalates has been reported to be $6.5 \mathrm{~h}$ (1a), $5.5 \mathrm{~h}$ (1b), and $5.7 \mathrm{~h}$ (1c), respectively. ${ }^{16}$ Di-tert-butyl peroxyoxalate ${ }^{21}$ and nitroxide $\mathbf{2}^{22}$ were prepared by the literature procedures.

(20) Lias, S. G.; Bartmess, J . E.; Liebman, J . F.; Holmes, J . L.; Levin, R. D.; Mallard, W. G. J . Phys. Chem. Ref. Data 1988, 17, Suppl. 1.

(21) Bartlett, P. D.; Benzing, E. P.; Pincock, R. E.J . Am. Chem. Soc. 1960, 82, 1762-1768.

(22) Griffith, P. G.; Moad, G.; Rizzardo, E.; Solomon, D. H. Aust. J . Chem. 1983, 36, 397-401. 
Trapping Experiments. A solution of $\mathbf{1}(0.040 \mathrm{M})$ and $\mathbf{2}$ $(0.040 \mathrm{M})$ in freshly distilled styrene was degassed by three successive freeze-pump-thaw cycles to $10^{-4} \mathrm{mmHg}$ ). A relatively low concentration of $\mathbf{2}$ was used in order to study the competitive reaction of alkyl radicals with styrene. However, under the conditions of the reaction, $\mathbf{2}$ is still present in excess because of the low conversion $(<15 \%)$ and the $<100 \%$ efficiency of generation of radicals from 1.12 The reaction vessel was then sealed under vacuum and heated at $60 \pm 0.1^{\circ}$ $\mathrm{C}$ for $1.0 \mathrm{~h}$. The majority (ca. $90 \%$ ) of excess monomer was then removed under reduced pressure prior to analysis by reversed-phase HPLC with methanol/water mixtures as the eluent. The HPLC-separated products were identified by electrospray mass spectrometry. Products 4, 7, 8, 9b,c, and 11 were also identified by cochromatography with authentic samples. New compounds were isolated by preparative HPLC and characterized by NMR.

Product Analysis. Analytical HPLC studies were carried out with a Shimadzu LC-9A liquid chromatograph fitted with either a Waters Nova-Pak $\mathrm{C}_{18} 6 \mathrm{~mm}, 100 \times 8 \mathrm{~mm}$ ODS analytical column or a Rainin Instruments Dynamax-60A 8 $\mathrm{mm} 250 \times 4.6 \mathrm{~mm} \mathrm{C}_{18}$ analytical column, connected to a Shimadzu UV spectrophotometric detector set at $270 \mathrm{~nm}$ and a CR-6A computing integrator.

Peak areas were determined by integration of HPLC chromatograms. Allowance for differing chromophores was made either by determining the extinction coefficients at $270 \mathrm{~nm}$ of the isolated products or by the reinjection of solutions of known concentration to assess peak response ratios for the UV detector. The adjusted peak areas were converted into relative product yields and normalized to $100 \%$.

The reaction products were isolated using preparative reversed-phase HPLC on a Rainin I nstruments Dynamax-60A 8 $\mu \mathrm{m} 250 \times 21.4 \mathrm{~mm} \mathrm{C}_{18}$ preparative column. Compounds were detected by a Soma UV detector S-310A fitted with a 1.0 $\mathrm{mm}$ preparative cell. Solvent flow rates were variable depending upon the methanol-water ratio and the back pressure, which was kept less than 2500 psi by a Gilson 303 pump fitted with a $25 \mathrm{~cm}^{3} \mathrm{~min}^{-1}$ preparative head and $803 \mathrm{C}$ manometric module.

NMR spectra were recorded on a Varian Gemini-200 (200 $\mathrm{MHz}$ ) spectrometer, using deuterated chloroform as solvent. Chemical shifts for ${ }^{1} \mathrm{H}$ NMR spectra are relative to residual $\mathrm{CHCl}_{3}(\delta 7.24 \mathrm{ppm})$ and for ${ }^{13} \mathrm{C} \mathrm{NMR}$ spectra are relative to the central peak of the triplet resonance due to $\mathrm{CDCl}_{3}(\delta 77.0$ ppm).

HPLC-electrospray mass spectra were obtained with a single quadrupole VG Platform II mass spectrometer, coupled to a MassLynx data system

The new compounds and a known compound $6 \mathbf{a}\left({ }^{13} \mathrm{C}\right.$ NMR data not previously reported) were isolated by preparative HPLC and characterized by the NMR data listed below.

2-(3,3-Dimethyl-1-phenylbutoxy)-1,1,3,3-

tetramethyl-2,3-dihydro-1H-isoindole (5): $\delta_{\mathrm{H}} \quad\left(\mathrm{CDCl}_{3}\right)$ 7.44-6.92 (9H), 4.73 (dd, J = 10.4, 3.3 Hz, 1H), 2.18 (dd, $\mathrm{J}=13.6,3.3 \mathrm{~Hz}, 1 \mathrm{H}), 1.96(\mathrm{dd}, \mathrm{J}=13.6,10.4 \mathrm{~Hz}, 1 \mathrm{H}), 1.65$ $(\mathrm{s}, 3 \mathrm{H}), 1.43(\mathrm{~s}, 3 \mathrm{H}), 1.18(\mathrm{~s}, 3 \mathrm{H}), 0.82(\mathrm{~s}, 9 \mathrm{H}), 0.64(\mathrm{~s}, 3 \mathrm{H}) ; \delta_{\mathrm{C}}$ $\left(\mathrm{CDCl}_{3}\right)$ 145.6, 145.1, 144.7, 129.0, 127.9, 127.6, 127.1, 121.7, $121.4,85.6,67.9,66.9,48.8,30.6,30.4,29.1,25.9,25.3 ; \mathrm{m} / \mathrm{z} 374$ $(\mathrm{M}+\mathrm{Na})^{+}, 352(\mathrm{M}+\mathrm{H})^{+}$.
2-(2-tert-Butoxy-1-phenylethoxy)-1,1,3,3tetramethyl-2,3-dihydro-1H-isoindole (6a): ${ }^{13} \delta_{\mathrm{C}}\left(\mathrm{CDCl}_{3}\right)$ 145.6, 145.3, 142.2, 128.1, 127.8, 127.7, 127.0, 121.6, 121.4 $88.9,73.1,68.4,66.9,65.6,29.5,29.4,27.6,25.4 ; \mathrm{m} / \mathrm{z} 390$ (M + $\mathrm{Na})^{+}, 368(\mathrm{M}+\mathrm{H})^{+}$.

2-[2-(tert-Pentyloxy)-1-phenylethoxy]-1,1,3,3-tetramethyl-2,3-dihydro-1H-isoindole (6b): $\delta_{\mathrm{H}}\left(\mathrm{CDCl}_{3}\right)$ 7.44-6.94 $(9 \mathrm{H}), 4.87(\mathrm{dd}, \mathrm{J}=8.4,4.1 \mathrm{~Hz}, 1 \mathrm{H}), 3.78(\mathrm{dd}, \mathrm{J}=10.0,8.4 \mathrm{~Hz}$, $1 \mathrm{H}), 3.38(\mathrm{dd}, \mathrm{J}=10.0,4.1 \mathrm{~Hz}, 1 \mathrm{H}), 1.52(\mathrm{q}, \mathrm{J}=7.5 \mathrm{~Hz}, 2 \mathrm{H})$, $1.69(\mathrm{~s}, 3 \mathrm{H}), 1.51(\mathrm{~s}, 3 \mathrm{H}), 1.26(\mathrm{~s}, 3 \mathrm{H}), 1.16(\mathrm{~s}, 3 \mathrm{H}), 1.15(\mathrm{~s}$, $3 \mathrm{H}), 0.88(\mathrm{t}, \mathrm{J}=7.5 \mathrm{~Hz}, 3 \mathrm{H}), 0.77(\mathrm{~s}, 3 \mathrm{H}) ; \delta_{\mathrm{C}}\left(\mathrm{CDCl}_{3}\right) 145.6$ 145.3, 142.3, 128.0, 127.8, 127.7, 127.0, 121.6, 121.4, 88.7, 75.1, $68.3,66.9,65.1,33.0,29.6,29.4,25.3,25.0,24.8,8.4 ; \mathrm{m} / \mathrm{z} 404$ $(\mathrm{M}+\mathrm{Na})^{+}, 382(\mathrm{M}+\mathrm{H})^{+}$

2-[2-(tert-Hexyloxy)-1-phenylethoxy]-1,1,3,3-tetramethyl-2,3-dihydro-1H-isoindole (6c): $\delta_{\mathrm{H}}\left(\mathrm{CDCl}_{3}\right)$ 7.45-6.94 $(9 \mathrm{H}), 4.87$ (dd, J = 8.4, $4.1 \mathrm{~Hz} 1 \mathrm{H}$ ), 3.80 (dd, J $=10.0,8.4 \mathrm{~Hz}$, $1 \mathrm{H}), 3.40$ (dd, $\mathrm{J}=10.0,4.1 \mathrm{~Hz}, 1 \mathrm{H}), 1.70(\mathrm{~s}, 3 \mathrm{H}), 1.52(\mathrm{~s}, 3 \mathrm{H})$ $1.50-1.24(\mathrm{~m}, 4 \mathrm{H}), 1.28(\mathrm{~s}, 3 \mathrm{H}), 1.18(\mathrm{~s}, 3 \mathrm{H}), 1.16(\mathrm{~s}, 3 \mathrm{H}), 0.91$ $(\mathrm{t}, \mathrm{J}=7.0 \mathrm{~Hz}, 3 \mathrm{H}), 0.78(\mathrm{~s}, 3 \mathrm{H}) ; \delta_{\mathrm{C}}\left(\mathrm{CDCl}_{3}\right) 145.6,145.4,142.3$ $128.1,127.9,127.7,127.6,127.1,121.7,121.4,88.7,75.0,68.4$ $66.9,65.1,43.1,29.6,29.4,25.5,25.3,17.3,14.8 ; \mathrm{m} / \mathrm{z} 418$ (M

$+\mathrm{Na})^{+}, 396(\mathrm{M}+\mathrm{H})^{+}$.

2-(1-Phenylbutoxy)-1,1,3,3-tetramethyl-2,3-dihydro1H-isoindole (10b): $\delta_{\mathrm{H}}\left(\mathrm{CDCl}_{3}\right) 7.40-6.94(9 \mathrm{H}), 4.68$ (dd, J $=8.1,6.1 \mathrm{~Hz}, 1 \mathrm{H}), 2.21-2.03(\mathrm{~m}, 1 \mathrm{H}), 1.86-1.67(\mathrm{~m}, 1 \mathrm{H}), 1.5-$ $1.2(\mathrm{~m}, 2 \mathrm{H}), 1.63(\mathrm{~s}, 3 \mathrm{H}), 1.45(\mathrm{~s}, 3 \mathrm{H}), 1.24(\mathrm{~s}, 3 \mathrm{H}), 0.94(\mathrm{t}, \mathrm{J}=$ $7.3 \mathrm{~Hz}, 3 \mathrm{H}), 0.72(\mathrm{~s}, 3 \mathrm{H}) ; \delta_{\mathrm{C}}\left(\mathrm{CDCl}_{3}\right) 145.5,145.2,143.9,128.0$, $127.7,127.4,127.1,127.0,121.7,121.3,88.0,68.0,66.9,38.3$, $30.2,29.3,25.7,25.2,19.5,14.2 ; \mathrm{m} / \mathrm{z} 346(\mathrm{M}+\mathrm{Na})^{+}, 324(\mathrm{M}+$ $\mathrm{H})^{+}$.

2-[(1-Phenylpentyl)oxy]-1,1,3,3-tetramethyl-2,3-dihydro1H-isoindole (10c): $\delta_{\mathrm{H}}\left(\mathrm{CDCl}_{3}\right) 7.40-6.94(9 \mathrm{H}), 4.66$ (dd, J $=8.2,6.1 \mathrm{~Hz}, 1 \mathrm{H}), 2.24-2.04(\mathrm{~m}, 1 \mathrm{H}), 1.88-1.68(\mathrm{~m}, 1 \mathrm{H}), 1.63$ $(\mathrm{s}, 3 \mathrm{H}), 1.5-1.1(\mathrm{~m}, 4 \mathrm{H}), 1.45(\mathrm{~s}, 3 \mathrm{H}), 1.23(\mathrm{~s}, 3 \mathrm{H}), 0.89(\mathrm{t}, \mathrm{J}=$ $7.0 \mathrm{~Hz}, 3 \mathrm{H}), 0.72(\mathrm{~s}, 3 \mathrm{H}) ; \delta_{\mathrm{C}}\left(\mathrm{CDCl}_{3}\right) 145.5,145.1,144.0,128.0$ $127.7,127.4,127.1,127.0,121.7,121.4,88.2,68.0,67.0,35.7$, $30.2,29.3,28.4,25.7,25.2,22.9,14.1 ; \mathrm{m} / \mathrm{z} 360(\mathrm{M}+\mathrm{Na})^{+}, 338$ $(\mathrm{M}+\mathrm{H})^{+}$.

2-[(6-Hydroxy-6-methyl-1-phenylheptyl)oxy]-1,1,3,3tetramethyl-2,3-dihydro-1H-isoindole (12): $\delta_{\mathrm{H}}\left(\mathrm{CDCl}_{3}\right)$ 7.40-6.94 (9H), $4.66(\mathrm{dd}, \mathrm{J}=8.2,6.2 \mathrm{~Hz}, 1 \mathrm{H}), 2.24-2.04(\mathrm{~m}$, $1 \mathrm{H}), 1.88-1.68(\mathrm{~m}, 1 \mathrm{H}), 1.63(\mathrm{~s}, 3 \mathrm{H}), 1.6-1.1(\mathrm{~m}, 6 \mathrm{H}), 1.45(\mathrm{~s}$, $3 \mathrm{H}), 1.23(\mathrm{~s}, 3 \mathrm{H}), 1.20(\mathrm{~s}, 6 \mathrm{H}), 0.73(\mathrm{~s}, 3 \mathrm{H}) ; \delta_{\mathrm{C}}\left(\mathrm{CDCl}_{3}\right)$ 145.4, $145.1,143.8,128.0,127.7,127.5,127.1,127.0,121.7,121.4$, 88.2, 71.0, 68.0, 67.0, 43.9, 36.0, 30.3, 29.3, 26.8, 25.7, 25.3, 24.5; $\mathrm{m} / \mathrm{z} 418(\mathrm{M}+\mathrm{Na})^{+}, 396(\mathrm{M}+\mathrm{H})^{+}$.

Reaction of tert-Butoxyl Radicals with Styrene in the Presence of 2. The reaction of di-tert-butyl peroxyoxalate $(0.040 \mathrm{M})$ with styrene in the presence of $2(0.090 \mathrm{M})$ was carried out at $60{ }^{\circ} \mathrm{C}$ for $1.5 \mathrm{~h}$ in the same manner as above.

Acknowledgment. We thank NOF Corporation, Griffith University, and the Australian Research Council for financial assistance. 